\title{
Insights on the Source of the 28 September 2018 Sulawesi Tsunami, Indonesia Based on Spectral Analyses and Numerical Simulations
}

\author{
Mohammad Heidarzadeh, ${ }^{1}$ (D) Abdul Muhari, ${ }^{2}$ and Antonius B. Wijanarto ${ }^{3}$
}

\begin{abstract}
The 28 September 2018 Sulawesi tsunami has been a puzzle because extreme deadly tsunami waves were generated following an $M w 7.5$ strike-slip earthquake, while such earthquakes are not usually considered to produce large tsunamis. Here, we obtained, processed and analyzed two sea level records of the tsunami in the near-field (Pantoloan located inside the Palu Bay) and far-field (Mamuju located outside the Palu Bay) and conducted numerical simulations to shed light on the tsunami source. The two tide gauges recorded maximum tsunami trough-to-crest heights of 380 and $24 \mathrm{~cm}$, respectively, with respective dominating wave periods of 3.6-4.4 and $10 \mathrm{~min}$, and respective high-energy wave duration of 5.5 and $>14 \mathrm{~h}$. The two observed waveforms were significantly different with wave amplitude and period ratios of $\sim 16$ and $\sim 3$, respectively. We infer tsunamigenic source dimensions of $3.4-4.1 \mathrm{~km}$ and $32.5 \mathrm{~km}$, for inside and outside of the Palu Bay, respectively. Our numerical simulations fairly well reproduced both tsunami observations in Pantoloan and Mamuju; except for the arrival time in Mamuju. However, it was incapable of reproducing the maximum reported coastal amplitudes of 6-11 m. It is possible that these two sources are different parts of the same tectonic source. A bay oscillation mode of $\sim 85$ min was revealed for the Palu Bay through numerical modeling. Actual sea surface disturbances and landslide-generated waves were captured by two video recordings from inside the Palu Bay shortly after the earthquake. It is possible that a large submarine landslide contributed to and intensified the Sulawesi tsunami. We identify the southern part of the Palu Bay, around the latitude of $-0.82^{\circ} \mathrm{S}$, as the most likely location of a potential landslide based on our backward tsunami ray tracing analysis. However, marine geological data from the Palu Bay are required to confirm such hypothesis.
\end{abstract}

Key words: Tsunami, earthquake, Sulawesi earthquake, numerical simulations, Indonesia, spectral analysis.

1 Department of Civil and Environmental Engineering, Brunel University London, Uxbridge UB8 3PH, UK. E-mail: mohammad.heidarzadeh@brunel.ac.uk

2 Ministry of Marine Affairs and Fisheries, Jakarta 10110, Indonesia.

3 Badan Informasi Geospasial, Cibinong, Indonesia.

\section{Introduction}

The Sulawesi Island of Indonesia was the site of a large earthquake $(M w 7.5)$ on 28 September 2018 which was followed by a deadly tsunami. The United States Geological Survey (USGS) located the epicenter at $0.178^{\circ} \mathrm{S}$ and $119.840^{\circ} \mathrm{E}$ occurring at 10:02:43 UTC at the depth of $10.0 \mathrm{~km}$ (Fig. 1). The USGS focal mechanism solution identified a dominant strike-slip mechanism with strike, dip and rake angles of the most likely fault plane as $350^{\circ}, 67^{\circ}$ and $-17^{\circ}$, respectively (red mechanism in Fig. 1). The fault plane from the gCMT (global CMT: http:// www.globalcmt.org) were: $348^{\circ}, 40^{\circ}$ and $-9^{\circ}$, respectively. Based on media reports and results of preliminary field surveys (Figure 2), the Sulawesi tsunami reached a maximum height of approximately 6-11 m along the coast of Palu within the Palu Bay (Fig. 1) (Muhari et al. 2018). As of 10 October 2018, the reported number of deaths has been 1763, making the Sulawesi event as the deadliest event in Indonesia since the December 2004 Sumatra-Andaman earthquake and tsunami. It is likely that the number of deaths will increase in the following weeks. Indonesia has experienced several deadly tsunamis since the December 2004 tragedy ( $>130,000$ deaths; Synolakis and Kong, 2006) including the tsunamis of October 2010 Mentawai (408 deaths) (Satake et al. 2013), the 2006 West Java (668 deaths) (Fujii and Satake, 2006), and the March 2005 Nias-Simeulu (>915 deaths, mostly from earthquake) (Borrero et al. 2011).

From a tectonic point of view, the epicentral area around the Sulawesi Island is located within one of the most complicated tectonic zones of the world where four major tectonic plates meet: Pacific plate 

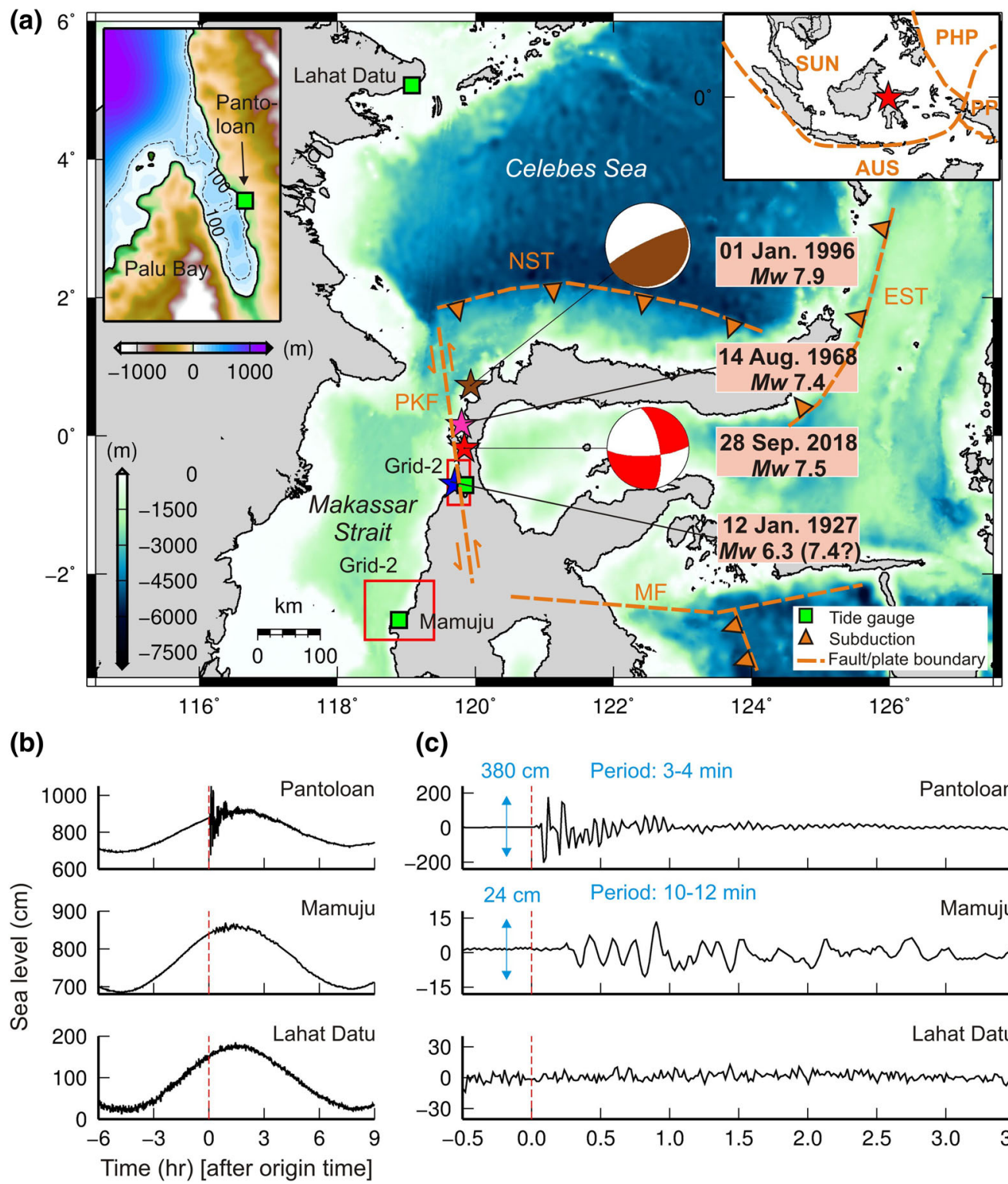

(c)

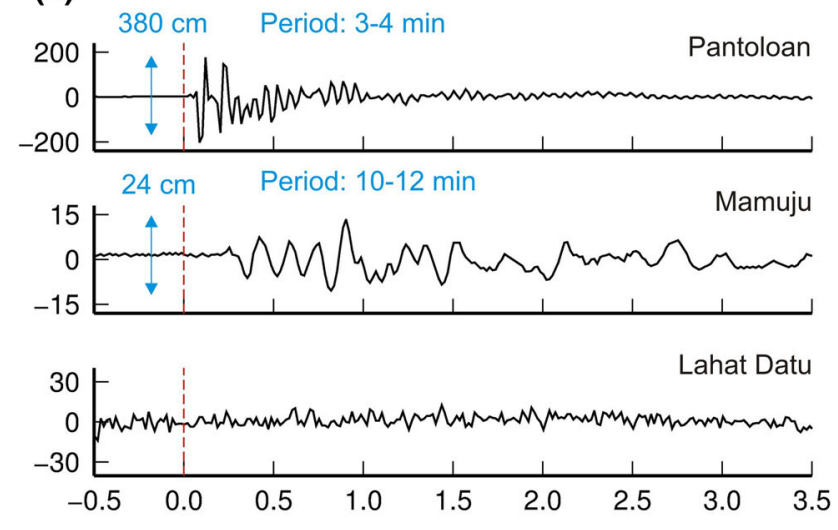

Figure 1

a The epicenter of the 28 September 2018 Sulawesi earthquake (red star) along with those of past large tsunamigenic earthquakes in the region (colored stars). The locations of tide gauges used in this study are shown by green solid squares. The focal mechanisms for the 1996 and 2018 events are from the USGS catalog. Abbreviations are: NST, North Sulawesi Trench; EST, East Sangihe Thrust; PKF, Palu-Koro Fault; MF, Matano Fault; SUN, Sunda Plate; PHP, Philippines Sea Plate; AUS, Australian Plate; PP, Pacific Plate. b Sea level records of the tsunami as registered on three tide gauge stations in the region. $\mathbf{c}$ De-tided sea level records showing clear tsunami records for the Pantoloan and Mamuju but no tsunami signal is apparent for the Lahat Datu station

from the east, the Philippine Sea plate from north, the Australian plate from south and the Sunda plate from the east (Fig. 1). The Palu-Koro strike-slip fault system (PKF) runs through the epicentral area (Fig. 1a). The Sulawesi region experienced at least three other lethal tsunamis in past hundred years (Fig. 1) in 1927 (M6.3, tsunami height of $15 \mathrm{~m}$ ), in 1968 (M7.4, tsunami height of 8-10 m, 392 deaths) and in 1996 (M7.7-7.8, tsunami height of $3.4 \mathrm{~m}, 9$ deaths) (Latief et al. 2000; Pelinovsky et al. 1997). 

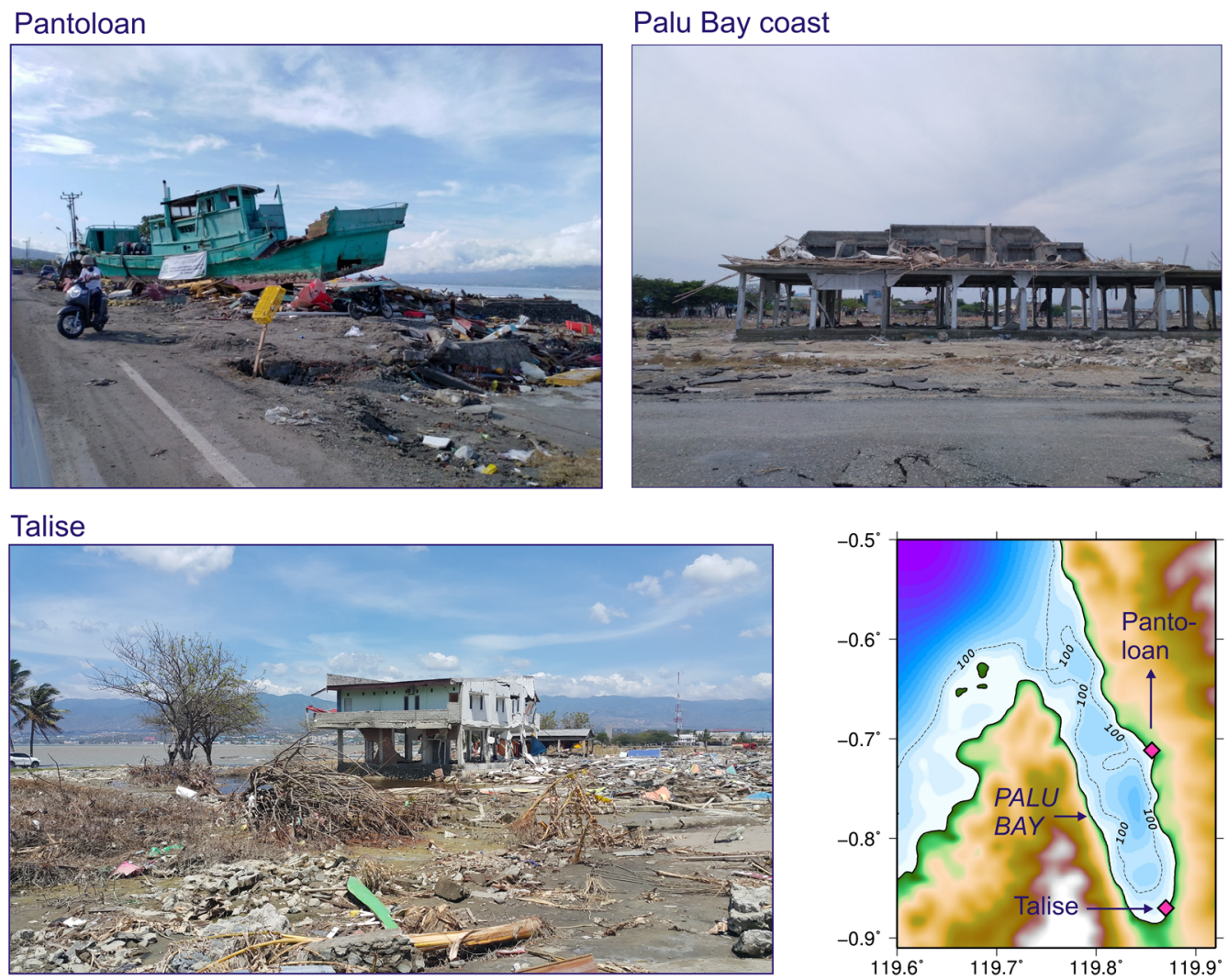

Figure 2

Photos of tsunami damage and inundation in Sulawesi. The dashed contour line at the bottom-right panel shows the water depth in meters. Photos belong to the authors

The 28 September 2018 Sulawesi event has been considered as a tsunami mystery because strike-slip earthquakes are usually unable to produce large tsunamis (Synolakis, 2003; Heidarzadeh et al. 2017) while the 2018 Sulawesi tsunami was $6-11 \mathrm{~m}$ in height along the coast. Strike-slip ruptures do not usually produce large vertical uplift/subsidence on the seafloor because of the dominant horizontal movements of the fault; thus, they are usually unable to produce destructive tsunamis. For example, the $M w$ 7.8 Wharton Basin earthquake in SW Sumatra, with a dominant strike-slip mechanism, generated tsunami amplitudes of less than $10 \mathrm{~cm}$ at tide gauges (Heidarzadeh et al. 2017). In addition, the size of the earthquake was $M w 7.5$ which is relatively small in terms of tsunami generation. Therefore, it has been speculated that the large waves of the 2018 Sulawesi tsunami were the results of secondary sources triggered by the main shock. Potential secondary sources are splay faulting, submarine landslides, bay oscillations and funneling effects of the Palu Bay (Fig. 1).

In this research, we present the observed waveforms of the tsunami and conduct analysis to explore the spectral contents of the waveforms. Numerical modeling of the tsunami is performed using the tectonic source of the tsunami in order to examine whether the tsunami could be generated by the purely-tectonic source or not. Results from spectral analysis are combined with numerical simulations to infer potential sources of the tsunami.

\section{The Earthquake Fault and Local Bathymetry}

The Palu-Koro strike-slip fault system (PKF) was most likely responsible for the $M w 7.5$ Sulawesi earthquake (Fig. 1, 3). According to Bellier et al. (2001), the left-lateral and north-south striking PKF 
(a) GEBCO data

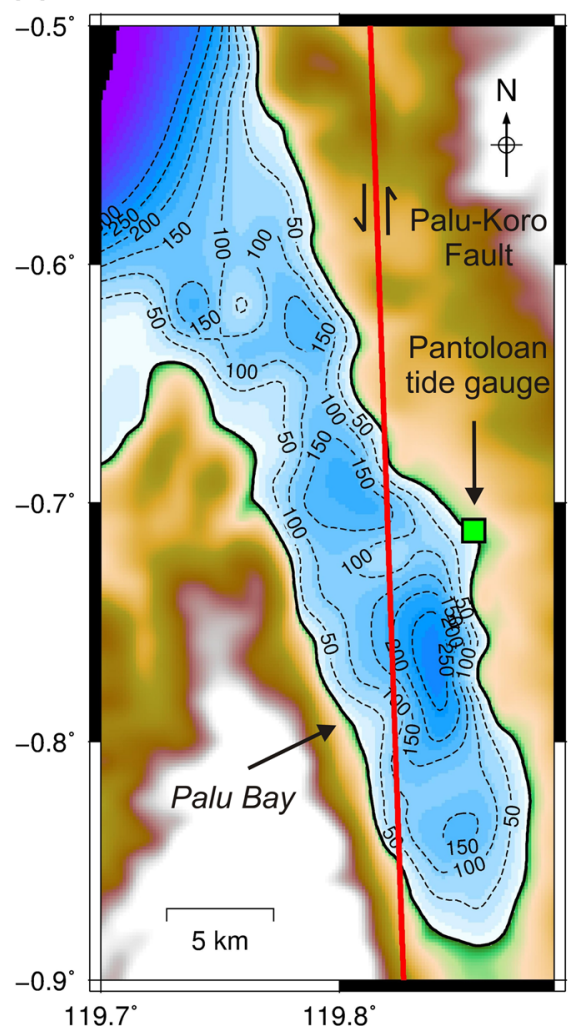

(b) BIG data

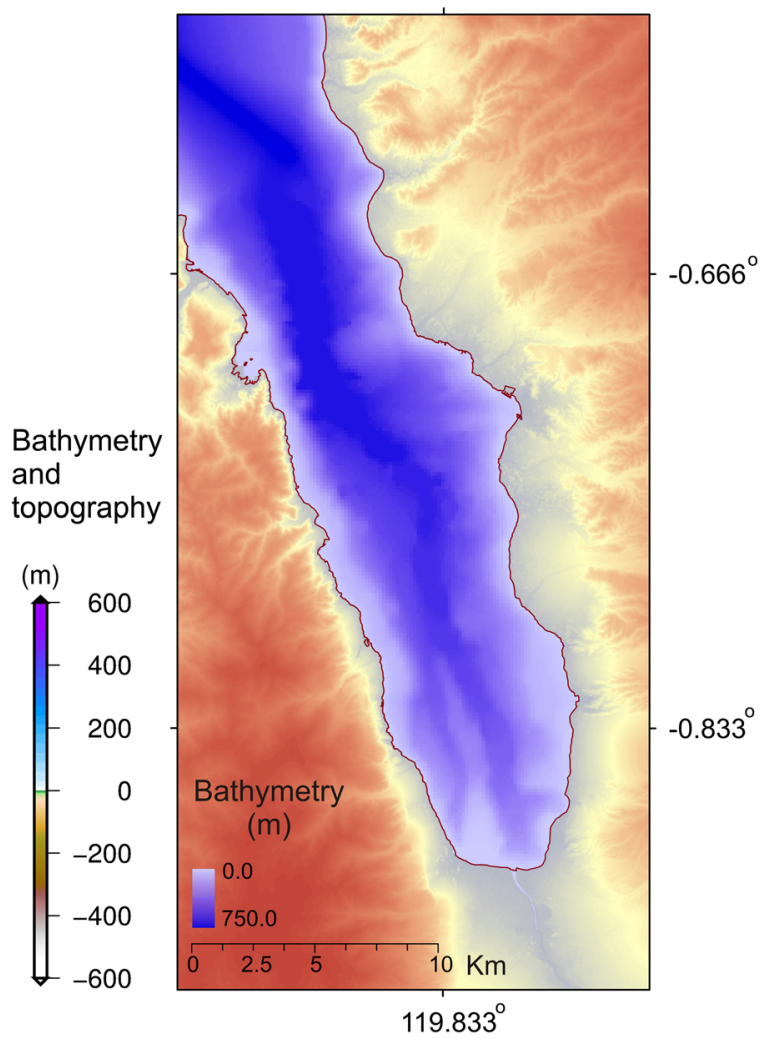

Figure 3

Bathymetry of the Palu Bay from GEBCO (a) and BIG (Badan Informasi Geospasial, Indonesia) (b) bathymetry data

system accommodates a horizontal slip rate of $35 \pm 8 \mathrm{~mm} / \mathrm{yr}$. Preliminary crustal displacement analysis using satellite images revealed up to several meters of horizontal displacement along the PKF system (http://www.gsi.go.jp/common/000205265. png). Most of the tsunami deaths were reported for the coast of Palu Bay which is a semi-enclosed basin with length and width of approximately 35 and $8 \mathrm{~km}$, respectively. The maximum water depth of the bay is approximately $300 \mathrm{~m}$ based on the coarse bathymetry data from the GEBCO digital atlas (Weatherall et al. 2015) (Fig. 3a). We note GEBCO bathymetry data may not be accurate enough for coastal and shallow areas such as the Palu Bay. The bathymetry data from BIG (Badan Informasi Geospasial, Indonesia) indicates a maximum water depth of $\sim 700 \mathrm{~m}$ (Fig. 3b) as a deep narrow channel in the middle of the bay.

\section{Data and Methods}

We analyzed three tide gauge records in Mamuju (Indonesia), Pantoloan (Indonesia) and Lahat Datu (Malaysia). All records have sampling intervals of 1 min. The Lahat Datu data was provided by the Intergovernmental Oceanographic Commission of UNESCO/UN at http://www.ioc-sealevelmonitoring. org/ while the other two records were obtained and processed by the Agency for Geo-spatial Information, Indonesia (BIG) (http://tides.big.go.id). Sea level data were de-tided by predicting the tidal signals using a least squares method of harmonic analysis and then removing the tidal signals from the original tide gauge records. For spectral analysis, we followed the Welch algorithm (Welch, 1967) with half-window overlaps (e.g., Rabinovich et al. 2011; Heidarzadeh and Satake, 2013). Duration of high-energy tsunami waves were calculated by the Averaged-Root-Mean- 
Square (ARMS) diagrams for the tsunami waveforms (Heidarzadeh and Satake, 2014) using a moving time window with length of $20 \mathrm{~min}$ (i.e., 20 data points). The duration of high-energy tsunami wave is the time that the ARMS level of the waveform is above that for the background wave (i.e., before the arrival of the tsunami).

For tsunami simulations, we applied the COMCOT package (Cornell Multi-grid Coupled Tsunami Model) (Liu et al. 1998; Wang and Liu, 2006). COMCOT solves linear and nonlinear Shallow Water Equations on both Cartesian and Spherical coordinates. COMCOT adapts a numerical scheme to mimic physical dispersion following the method by Imamura et al. (1988). A two-level nested bathymetric grid was created with resolutions of 30 and 5 arc-sec from the GEBCO-2014 (The General Bathymetric Chart of the Oceans) data (Weatherall et al. 2015) (Fig. 1a). The higher-resolution grid (i.e., level 2) was interpolated from the original GEBCO 30 arcsec bathymetry and topography data. We applied linear simulations for the larger grid and nonlinear simulations for the smaller ones. Runup calculations were not included in our numerical simulations, as it requires high-resolution nearshore bathymetry and topography. Simulations were conducted for a total time of $11 \mathrm{~h}$ with time step of $0.5 \mathrm{~s}$. The second version of the USGS source model has been used in this study for tsunami generation which has dimensions of $200 \mathrm{~km}$ (length) $\times 30 \mathrm{~km}$ (width) with maximum slip of $9 \mathrm{~m}$ occurring within the Palu Bay (https://earthquake.usgs.gov/earthquakes/eventpage/ us1000h3p4/finite-fault). The initial tsunami wave field was calculated using the co-seismic seafloor displacements obtained from the Okada's (1985) analytical method. Both vertical co-seismic displacement $\left(D_{z}\right)$ and the vertical water displacement due to steep slopes $\left(D_{h}\right)$ were considered following the approach proposed by Tanioka and Satake (1996):

$$
D_{h}=D_{x} \frac{d H}{d x}+D_{y} \frac{d H}{d y}
$$

in which, $D_{x}$ and $D_{y}$ are the E-W and N-S components of co-seismic seafloor displacement, $H$ is water depth (positive downward), $D_{h}$ is the vertical displacement of water due to the horizontal movement of the slope. The combined vertical displacement of water is the sum of $D_{z}$ and $D_{h}$.

\section{Results of Tide Gauge Data Analysis and Physical Properties of the Tsunami}

The Lahat Datu tide gauge did not record any clear tsunami signal (Fig. 1b) which can be attributed to the relatively large noise level $( \pm 8 \mathrm{~cm})$ and small size of the tsunami. The maximum trough-to-crest wave height recorded at two stations of Pantolaon (inside the Palu Bay) and Mamuju (outside the Palu Bay) are 380 and $24 \mathrm{~cm}$, respectively (Table 1, Figure 1c). The Pantoloan record is 16 times larger than that of the Mamuju. The respective arrival times are 5 and $19 \mathrm{~min}$ (Table 1). Our numerical simulations, however, indicate an arrival time of $\sim 45 \mathrm{~min}$ for the Mamuju record. Therefore, either the timing of the tide gauge was problematic or maybe a different mechanism was responsible for the early tsunami observed in Mamuju. Assuming that the latter holds

Table 1

Parameters of the Sulawesi tsunami of 28 September 2018 recorded by local tide gauges (Main shock, Mw = 7.5 at 10:02:43 UTC)

\begin{tabular}{|c|c|c|c|c|c|c|c|c|}
\hline \multirow[t]{2}{*}{ Station } & \multicolumn{3}{|c|}{ First wave } & \multicolumn{3}{|c|}{ Max waves } & \multirow{2}{*}{$\begin{array}{l}\text { Duration } \\
\text { high-energy } \\
\text { waves (h) }\end{array}$} & \multirow{2}{*}{$\begin{array}{l}\text { Visible } \\
\text { period } \\
(\mathrm{min})\end{array}$} \\
\hline & $\begin{array}{l}\text { Arrival } \\
\text { time } \\
\text { (UTC) }\end{array}$ & Travel time & $\begin{array}{l}\text { Amplitude } \\
(\mathrm{cm}) \text { Sign }\end{array}$ & $\begin{array}{l}\text { Max } \\
\text { amplitude } \\
(\mathrm{cm})\end{array}$ & $\begin{array}{l}\text { Time (UTC) } \\
\text { of max } \\
\text { amplitude }\end{array}$ & $\begin{array}{l}\text { Max wave } \\
\text { height } \\
(\mathrm{cm})\end{array}$ & & \\
\hline Pantoloan & $10: 07$ & $0 \mathrm{~h} 5 \mathrm{~min}$ & -203.4 & 176.4 & $10: 10$ & 379.8 & 5.5 & $3-4$ \\
\hline Mamuju & $10: 21$ & $0 \mathrm{~h} 19 \min ^{\mathrm{a}}$ & -6.9 & 14.3 & $10: 57$ & 24.2 & $>14$ & $10-12$ \\
\hline
\end{tabular}

${ }^{\mathrm{a}}$ Our numerical simulations indicate an arrival time of $\sim 45 \mathrm{~min}$ for the Mamuju record 
(a) Sulawesi tsunami (28 Sep. 2018 )

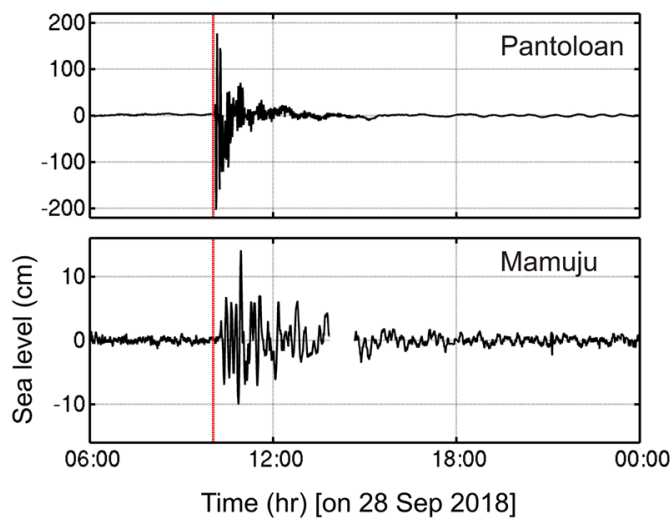

(b) Averaged root-mean square

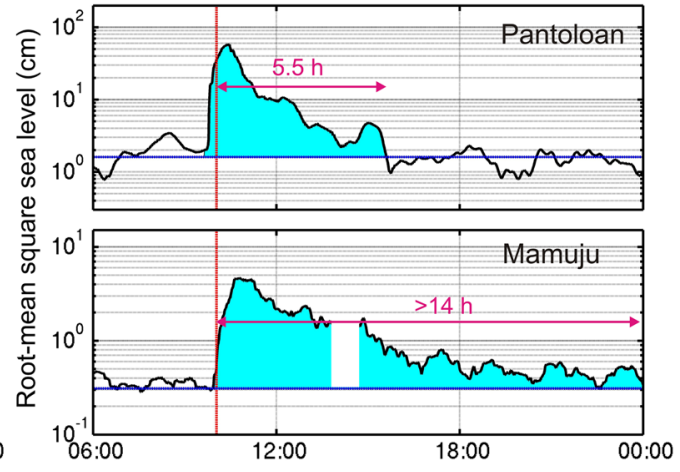

Figure 4

a The sea level records of the 28 September 2018 Sulawesi tsunami in Pantoloan and Mamuju. b Respective Averaged-Root-Mean-Square (ARMS) diagrams

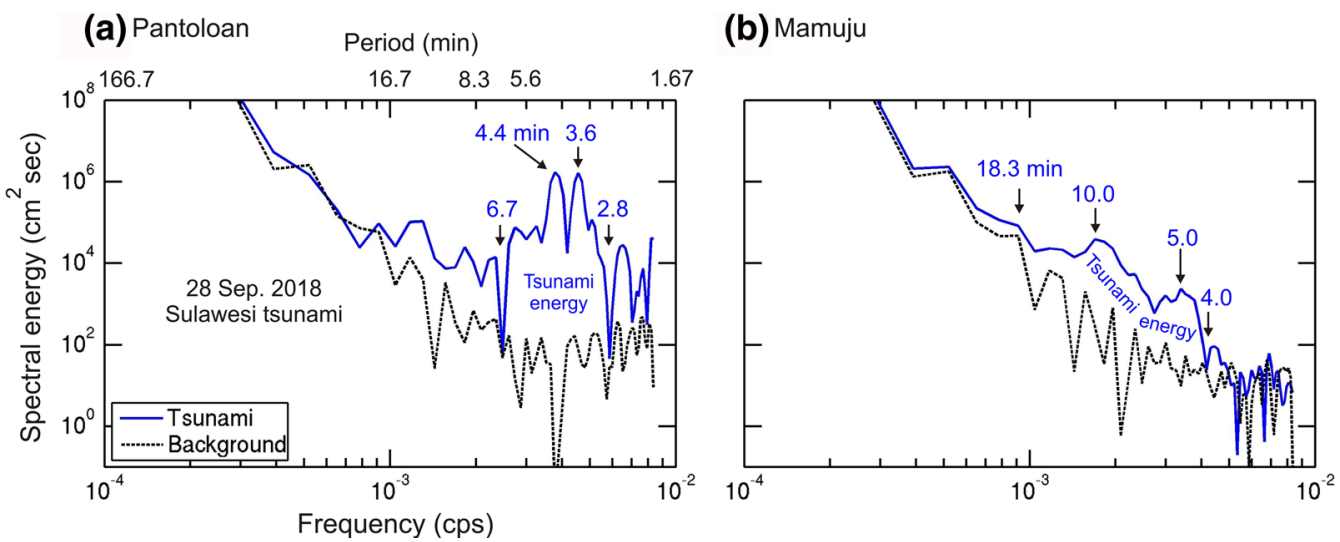

Figure 5

Spectral analysis for the sea level records of the 28 September 2018 Sulawesi tsunami in Pantoloan and Mamuju

true, the relatively short tsunami arrival time in Mamuju may indicate that other sources nearby were responsible for the tsunami in Mamuju.

In addition to such a significant difference in tsunami heights between Pantoloan and Mamuju, the two records are significantly different in terms of wave periods: their respective dominant periods are 3-4 and 10-12 min from inspection of the waveforms (Fig. 1c, Table 1). The dominant period of the Pantoloan waves are $\sim 3$ times longer than those of Mamuju. The sampling interval of 1 min appears to be insufficient to properly capture the short-period tsunami oscillations in Pantoloan; thus, the actual extrema of the waves are possibly higher than the values shown in Table 1. The ARMS diagrams (Fig. 4) show that the high-energy waves at the Pantoloan last for $5.5 \mathrm{~h}$ while they last for at least 14 $\mathrm{h}$ in Mamuju.

Tide gauge data analysis indicates that, in terms of physical properties of the waves, the Pantoloan and Mamuju tsunami waves are significantly different: the Pantoloan waves are significantly larger in height and are dominated by shorter-period waves and shorter duration in comparison to the waves at the Mamuju station. It appears that the two waveforms are possibly generated by two completely different sources or mechanisms. Usually different tide gauge records of the same tsunami contain the same or 

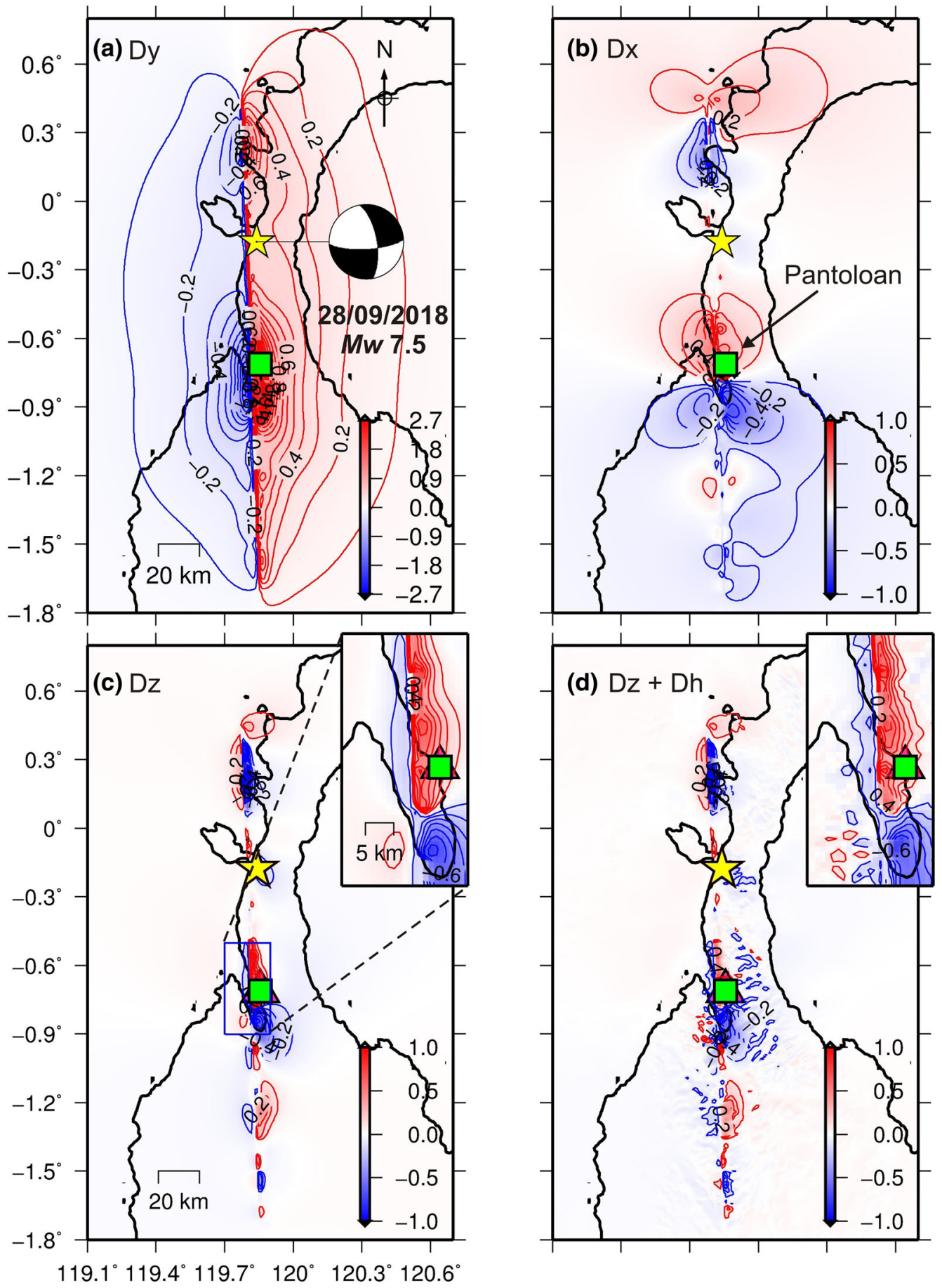

Figure 6

Co-seismic crustal displacement due to 28 September 2018 Sulawesi earthquake calculated using the revised source model on USGS. a The N-S component $\left(D_{y}\right)$. b the E-W component $\left(D_{x}\right)$. $\mathbf{c}$ the vertical component $\left(D_{z}\right)$. d combination of vertical component $\left(D_{z}\right)$ and the effect of steep bathymetry $\left(D_{h}\right)$ based on the methodology proposed by Tanioka and Satake (1996) 
Simulated tsunami amplitude $(\mathrm{cm})$ from $\mathrm{Dz}$
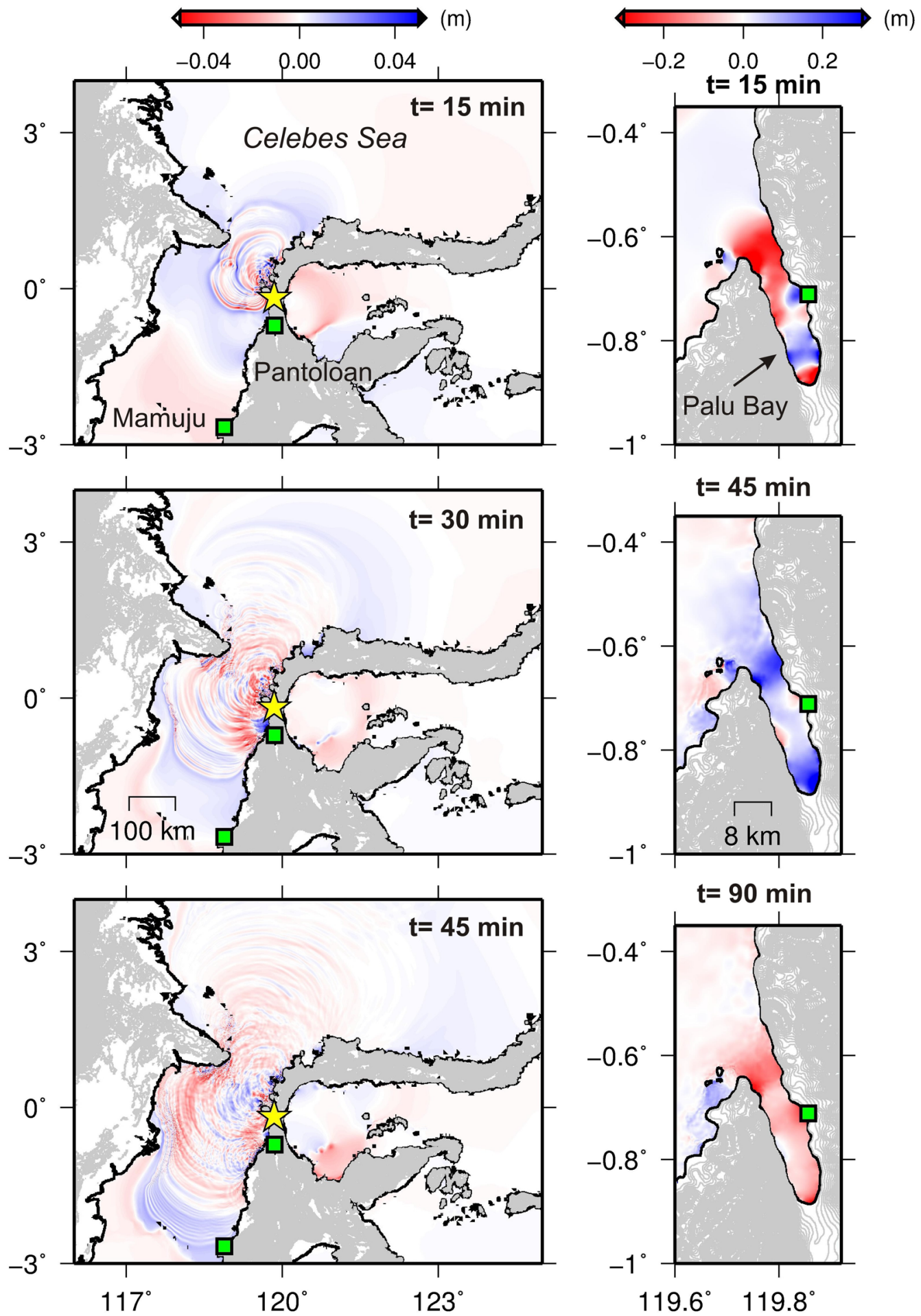
Figure 7

Snapshots of tsunami simulations in grid-1 (left) and grid-2 (right) at different times due to the 28 September 2018 Sulawesi tsunami. These snapshots are from the simulations based on the vertical coseismic displacement $\left(D_{z}\right)$

similar wave periods for at least the first few cycles (e.g., Heidarzadeh and Satake, 2013).

\section{Results of Spectral Analysis}

Spectral analyses (Fig. 5) reveal dominant tsunami period bands. For the Pantolaon station, the tsunami period band is $2.8-6.7 \mathrm{~min}$ while it is 4.0-18.3 min for Mamuju. The respective dominant tsunami periods are 3.6-4.4 and 10.0 min (Fig. 5). Tsunami source dimensions can be estimated from the tsunami dominant periods using the following equation (Heidarzadeh and Satake 2015b):

$$
L=\frac{T}{2} \sqrt{g H}
$$

in which, $L$ is source length, $H$ is average water depth, $g$ is gravitational acceleration and $T$ is tsunami dominant periods. We note that Equation (2) is applicable for wave periods $(T)$ extracted from first few cycles of the tsunami, which is usually free from bay oscillations and other bathymetric effects. By assuming average water depth of $\sim 100 \mathrm{~m}$ for inside the Palu Bay (Fig. 2) and $\sim 1200 \mathrm{~m}$ for outside the bay (Fig. 1), Eq. (2) results in tsunami source dimensions of approximately $3-4$ and $32-38 \mathrm{~km}$ for inside and outside the Palu Bay, respectively. We note that the average water depth of the Palu Bay could be slightly different considering the BIG bathymetry data in Fig. $3 b$. It is possible that these two sources are different parts of the same tectonic source because the isolated segment of the tectonic source located inside the Palu Bay may act independently towards tsunami generation within the bay.

\section{Results of Numerical Simulations}

Results of numerical simulations are shown in Figs. 6-11. Two different initial conditions for the
2018 Sulawesi tsunami were considered: the coseismic vertical crustal displacement (Fig. 6c, $D_{z}$ ), and the combination of the vertical component $\left(D_{z}\right)$ and the additional vertical water displacement due to the horizontal movement of the seafloor slope $\left(D_{h}\right)$ (Fig. 6d, the component $D_{z}+D_{h}$ ). It can be seen that these two initial conditions are similar to each other with small differences (Fig. 6). Our calculations yield up to $\sim 3$ and $\sim 1 \mathrm{~m}$ of co-seismic horizontal N-S (Fig. 6a) and E-W (Fig. 6b) crustal displacement. The maximum co-seismic vertical displacement is $\sim 1$ m (Fig. 6c, d).

Snapshots of tsunami simulations at different times for two large and small grids are shown in Figs. 7, 8 indicating a similar pattern of tsunami propagation from our two initial sources (i.e., $D_{z}$ and $D_{z}+D_{h}$ ). Several nodes (i.e., points with zero amplitude) appear in the tsunami snapshots within the Palu Bay (Figs 7, 8, right panels) indicating patterns of bay oscillations. Based on the snapshots in grid-1 (i.e., the largest grid), the first negative wave arrives in Mamuju $\sim 45$ min after the earthquake origin time while the observation waves show an arrival time of $\sim 20$ min (Fig. 1c). This may indicate that the timing of the Mamuju tide gauge station is not correct or possibly a different local source was responsible for the early tsunami in Mamuju. As the periods and amplitudes of the simulated and observed waves agree well at the Mamuju station, it is most likely that there was a clock error with the tide gauge. The simulated waves at the locations of the two tide gauges agree well with those of observations (Fig. 9, blue waveforms), at least for the first cycle of the waves. We note that the observation waveform in Mamuju is delayed $45 \mathrm{~min}$ in Fig. 9 to match the timing of the simulations. Tsunami simulations are usually aimed at reproducing the first wave cycle because later cycles are mixed with reflected/refracted waves as well as nonlinear bathymetry effects; hence, high-resolution bathymetry/topography data along with dispersive modeling would be necessary to fully reproduce late cycles. In such a context, the simulation results shown in Fig. 9 are successful in reproducing most of the features of the two observed tide gauge records.

Oscillations of tsunami waves at various locations within the Palu Bay are plotted in Fig. 10 based on 
Simulated tsunami amplitude $(\mathrm{cm})$ from $\mathrm{Dz}+\mathrm{Dh}$
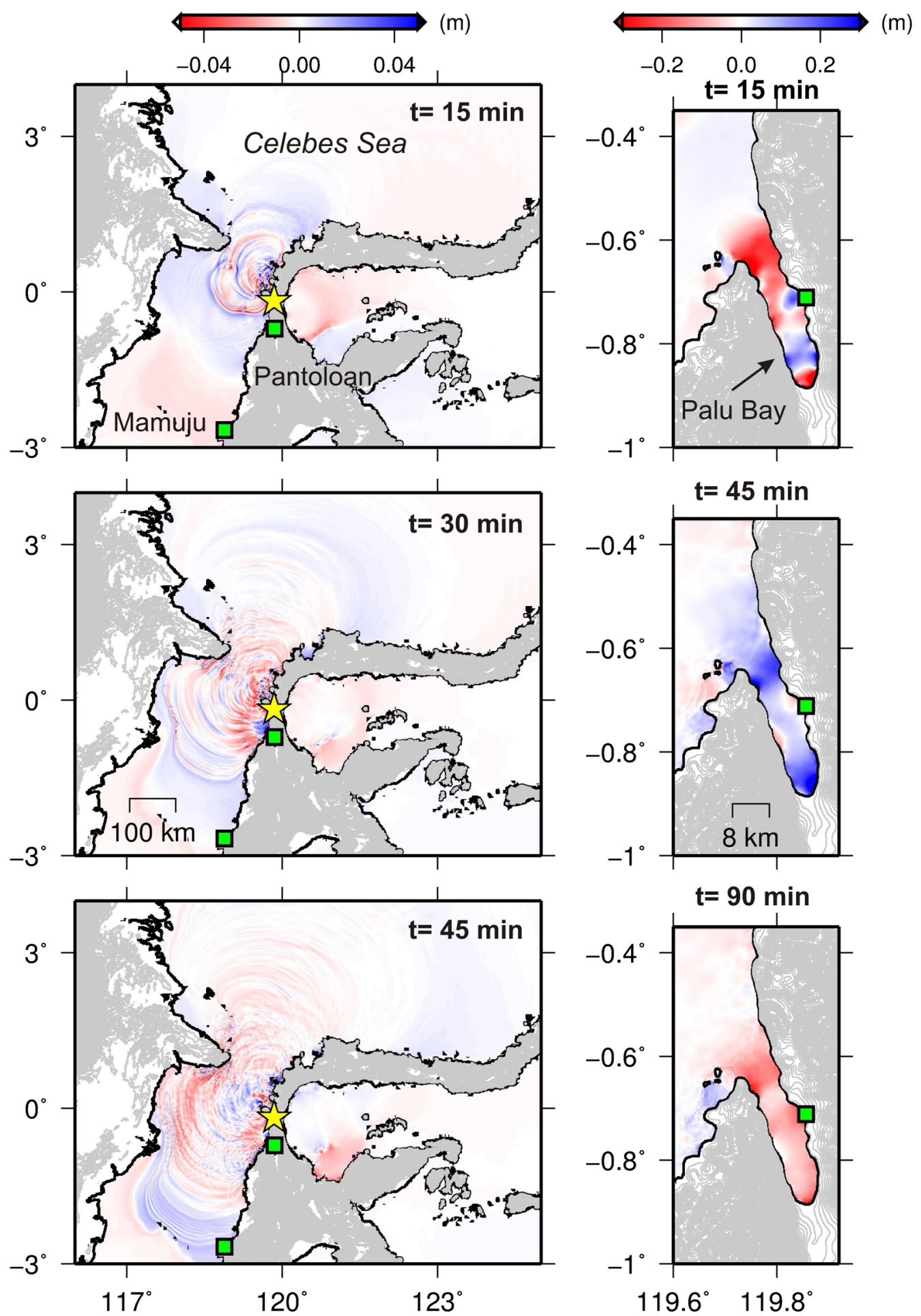
Figure 8

Snapshots of tsunami simulations in grid-1 (left) and grid-2 (right) at different times due to the 28 September 2018 Sulawesi tsunami. These snapshots are from the simulations based on the combination of the vertical co-seismic displacement and the vertical water displacement due to steep bathymetry $\left(D_{z}+D_{h}\right)$

our numerical simulations. A long period of $\sim 85 \mathrm{~min}$ is seen in all of the numerical wave gauges within the Palu Bay which can be attributed to the fundamental periods of the bay. According to Rabinovich (2010), the fundamental periods of a semi-enclosed long basin (i.e., length is significantly larger than the width) is given by the following equation:

$$
T=\frac{4 L}{(2 n+1)} \frac{1}{\sqrt{g H}}
$$

in which, $T$ is the fundamental mode of the bay, $L$ is the length of the bay, $H$ is average water depth, $g$ is gravitational acceleration and $n=0,1,2, \ldots$ which gives various fundamental modes. By assuming a length of $35 \mathrm{~km}(L)$ and an average water depth of $\sim 100 \mathrm{~m}(H)$, the few first fundamental periods are $75,25,15$ and $10.7 \mathrm{~min}$. The longest fundamental period of $75 \mathrm{~min}$ is close to the value of $\sim 85 \mathrm{~min}$ seen on the simulated waveforms in Fig. 10.

\section{(a) Simulations based on Dz}
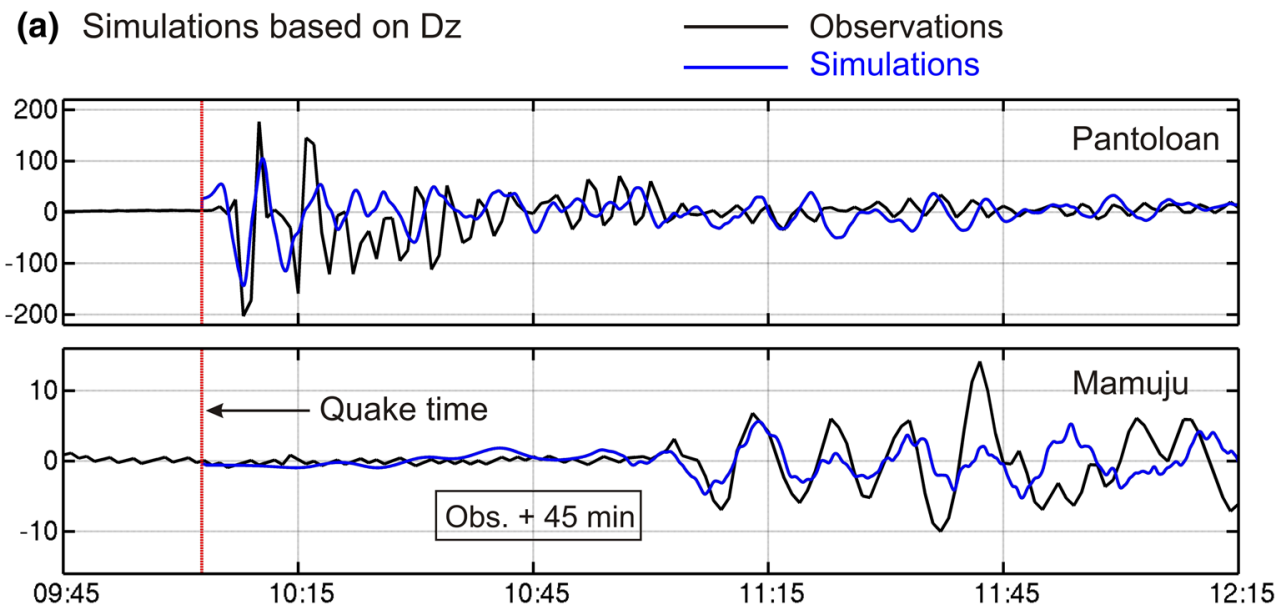

(b) Simulations based on Dz + Dh

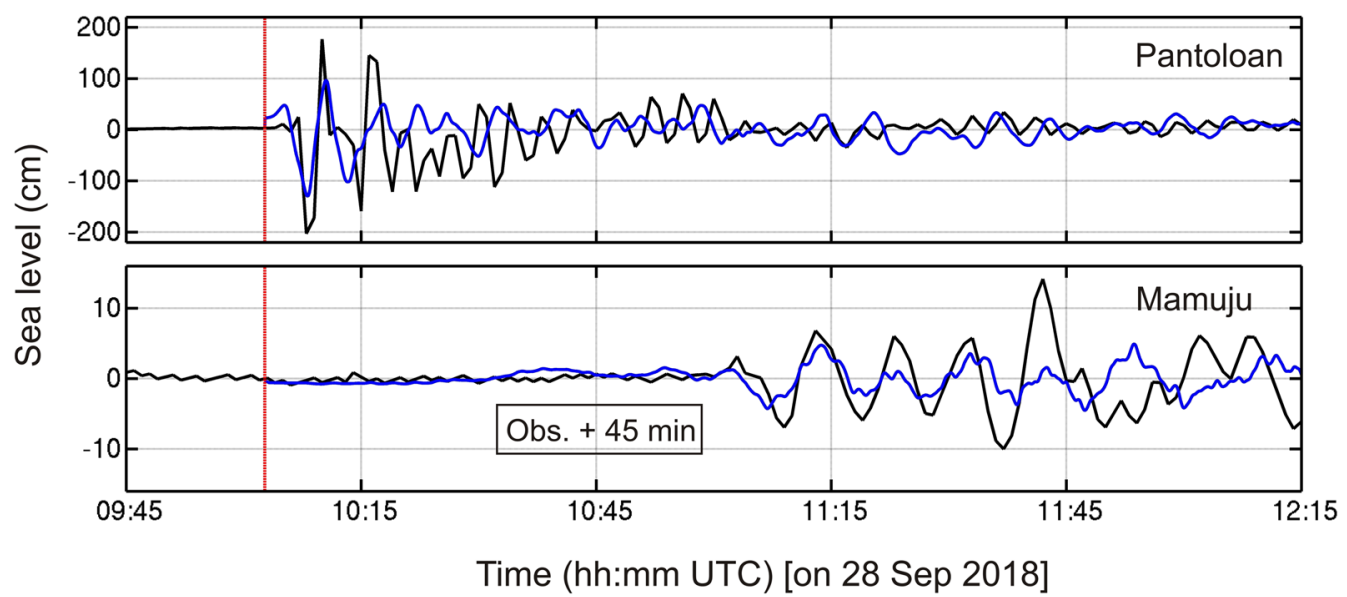

Figure 9

Comparison of observed (black) and simulated (red) waveforms of the 2018 Sulawesi tsunami. a Simulations are based on the vertical coseismic displacement $\left(D_{z}\right)$. b Same as "a" but for simulations based on the combination of the vertical co-seismic displacement $\left(D_{z}\right)$ and the vertical water displacement due to steep bathymetry $\left(D_{h}\right)$. Observation waveforms (Obs.) are shifted 45 min to match with the simulations. 

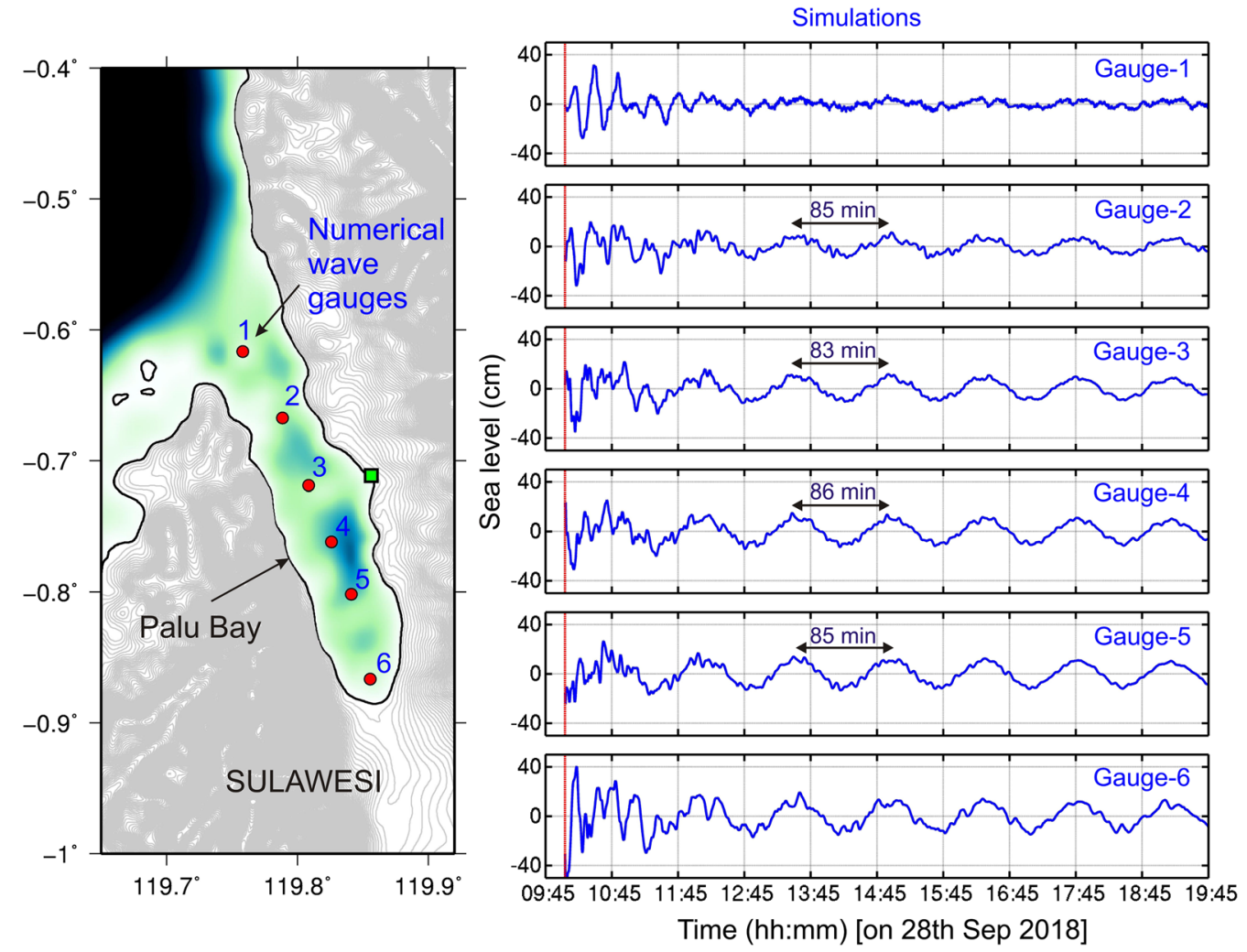

Figure 10

Tsunami simulations of the 28 September 2018 Sulawesi tsunami for various points within the Palu Bay revealing long-period waves with periods of $\sim 85$ min due to Bay oscillations. The red-dotted line indicates the origin time of the earthquake

The maximum tsunami wave amplitudes during the entire time of tsunami simulations are shown in Fig. 11 for both initial conditions. Figure 11, which does not include runup stage, yields maximum amplitude of $\sim 1.5 \mathrm{~m}$ for the Sulawesi tsunami. Previous studies have shown that maximum coastal wave amplitudes are rough estimates of wave runup. Obviously, this value is much smaller than the reported runup of 6-11 $\mathrm{m}$ by tsunami survey teams (Muhari et al. 2018). Based on Fig. 11, maximum wave amplitudes are concentrated at the southern tip of the Palu Bay as well as around the Pantoloan tide gauge station.

\section{Insights on the Source Mechanism and Potential Landslide Location}

Numerical modeling and spectral analysis conducted in this study help to comment on the type of the tsunami source. Based on the spectral analysis, the tide gauge stations located inside and outside of the Palu Bay generated tsunami waves with significantly-different dominating periods of 4.0 and 10.0 min, respectively. Numerical modeling proved that a purely-tectonic source of the tsunami is able to generate both types of the shorter- and longer-period waves inside and outside of the bay. However, the simulated maximum tsunami amplitudes $(1.5 \mathrm{~m})$ are smaller than the surveyed runup heights of 6-11 m inside of the Palu Bay. Therefore, it may be concluded that an additional secondary source has contributed to the tectonic source of the tsunami. We provide evidence in the next section that such a secondary source most likely was a submarine landslide within the Palu Bay.

To shed light on the location of a potential secondary landslide source, a backward tsunami ray tracing is conducted whose result is shown in Fig. 12. For this analysis, a hypothetical tsunami source is 
Maximum simulated tsunami amplitude

(a) due to $\mathrm{Dz}$
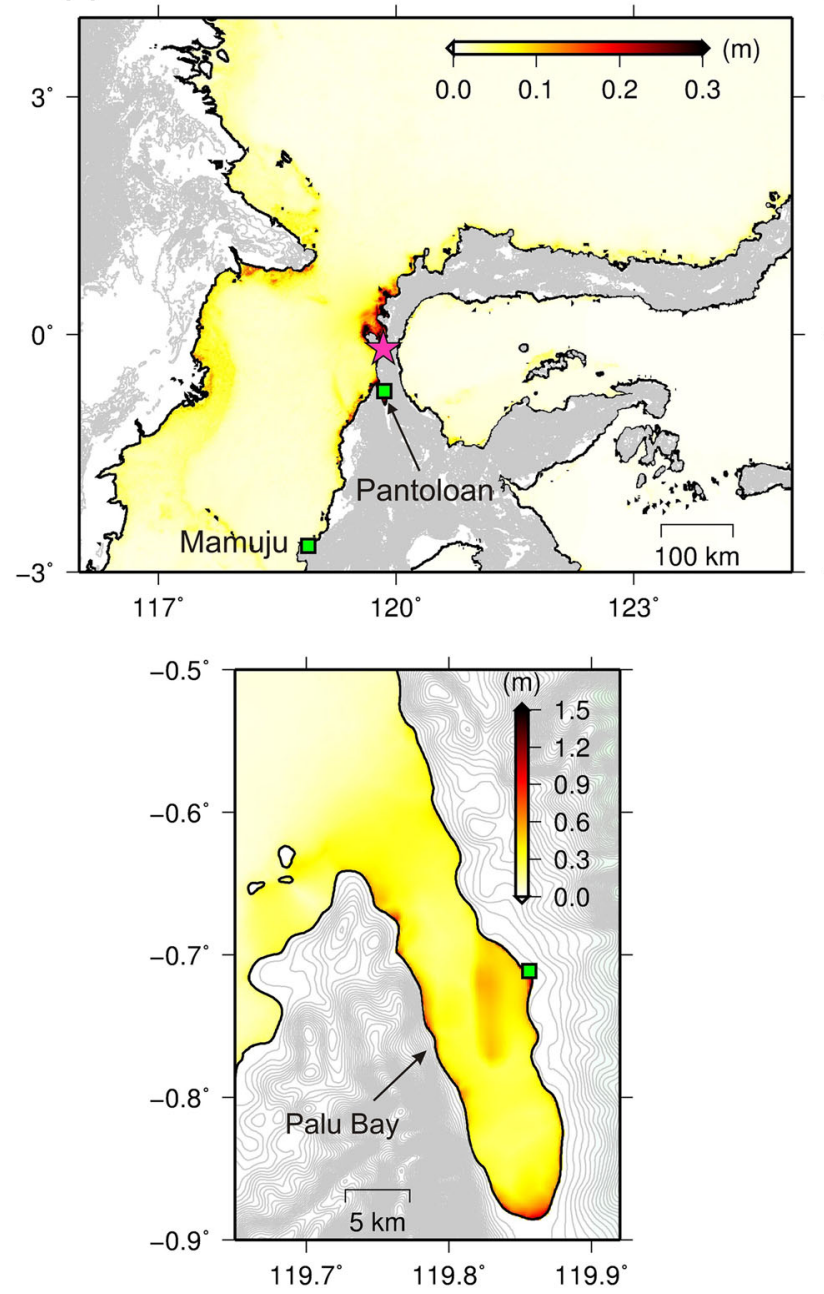

(b) due to $\mathrm{Dz}+\mathrm{Dh}$

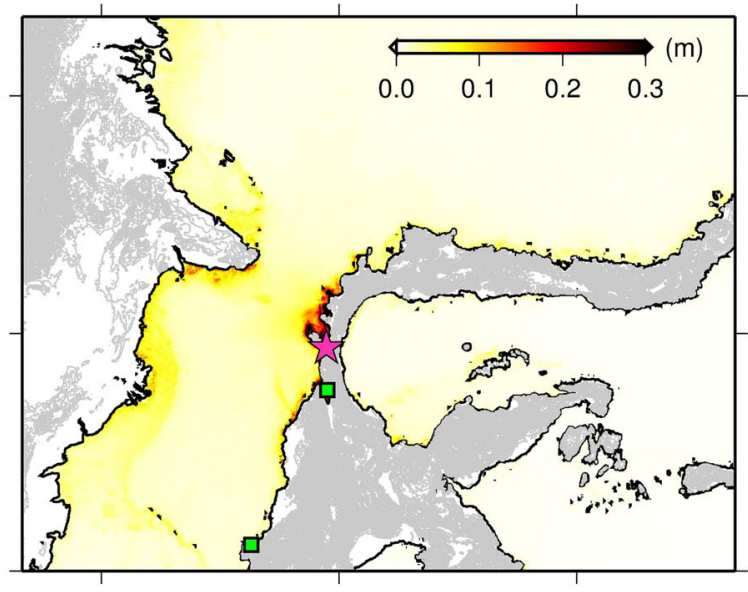

Figure 11

a Maximum tsunami amplitudes after $11 \mathrm{~h}$ of tsunami simulations based on the vertical co-seismic displacement $\left(D_{z}\right)$. b same as "a" but for simulations based on the combination of the vertical co-seismic displacement and the vertical water displacement due to steep bathymetry $\left(D_{z}+D_{h}\right)$

placed at the location of the Pantoloan tide gauge station and propagation of the tsunami is modelled up to $5 \mathrm{~min}$, which is the arrival time of the 2018 Sulawesi tsunami at this tide gauge station (Table 1). The edges of tsunami travel distances after $5 \mathrm{~min}$ in both directions (north and south) determine potential landslide locations (i.e., the two dashed boxes in the bottom-right panel in Fig. 12). The field survey by Muhari et al. (2018) revealed that the largest runup heights were concentrated at the southern part of the Palu Bay around the latitude of $-0.82^{\circ} \mathrm{S}$. Therefore, the bottom dashed rectangle at the latitude of $-0.82^{\circ} \mathrm{S}$ (Fig. 12) is more likely to be the location of a potential landslide.

\section{Discussion}

Our purely-tectonic source model for the 2018 Sulawesi tsunami reproduces fairly well both tide gauge records in Pantoloan and Mamuju; except for the arrival time of the Mamuju record. The agreement 

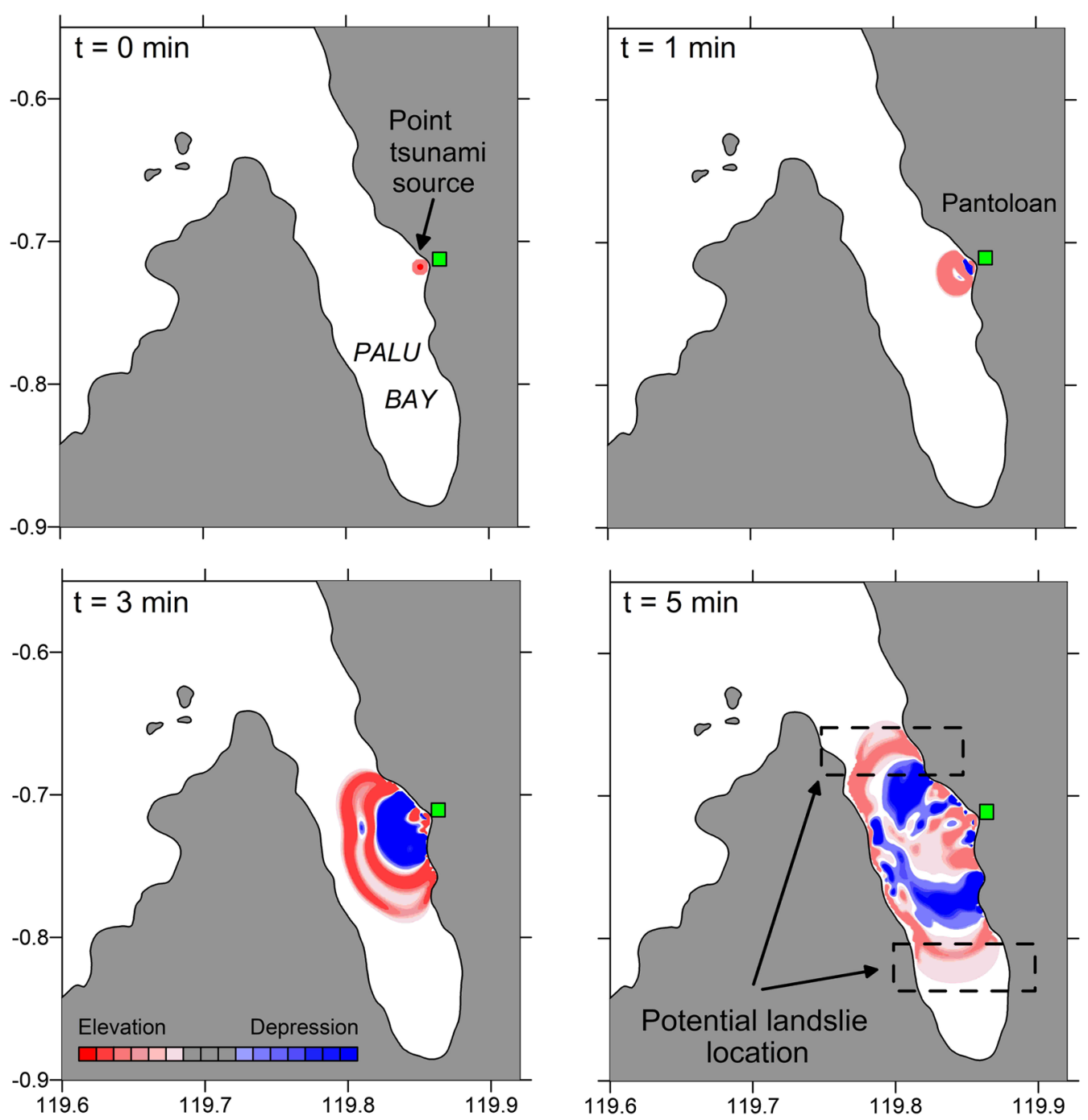

Figure 12

Results of backward tsunami ray tracing by placing a point tsunami source at the location of the Pantoloan tide gauge (top-left panel) and propagating the synthetic tsunami for $5 \mathrm{~min}$. The edges of tsunami travel distances after $5 \mathrm{~min}$ in both directions (north and south) determine potential landslide locations (i.e., the two dashed boxes in the bottom-right panel). The bottom dashed rectangle at the latitude of $-0.82^{\circ} \mathrm{S}$ is more likely to be the location of a potential landslide because largest runup heights of the 2018 Sulawesi tsunami were concentrated around this area

between our simulations with observations includes both wave periods and wave amplitudes. In other words, the purely-tectonic source model explains the sharp difference between wave amplitudes (i.e., a ratio of $\sim 16$ ) and wave periods (i.e., a ratio of $\sim 3$ ) of the Pantoloan and Mamuju tide gauge records. However, the maximum simulated coastal amplitudes from our source model is $\sim 1.5 \mathrm{~m}$ which are far less than the reported wave heights of $6-11 \mathrm{~m}$. As of 20
October 2018, preliminary tsunami field surveys have been conducted and the data on the runup are yet to be analyzed. It has been reported that the extreme wave height of $11 \mathrm{~m}$ was the splash height and perhaps the flow depth on the land was $\sim 3 \mathrm{~m}$ (Muhari et al. 2018). If we assume that these speculations hold true, then our source model could be capable of reproducing runup heights of $\sim 3 \mathrm{~m}$ given highresolution bathymetry/topography. Long-wave runup 

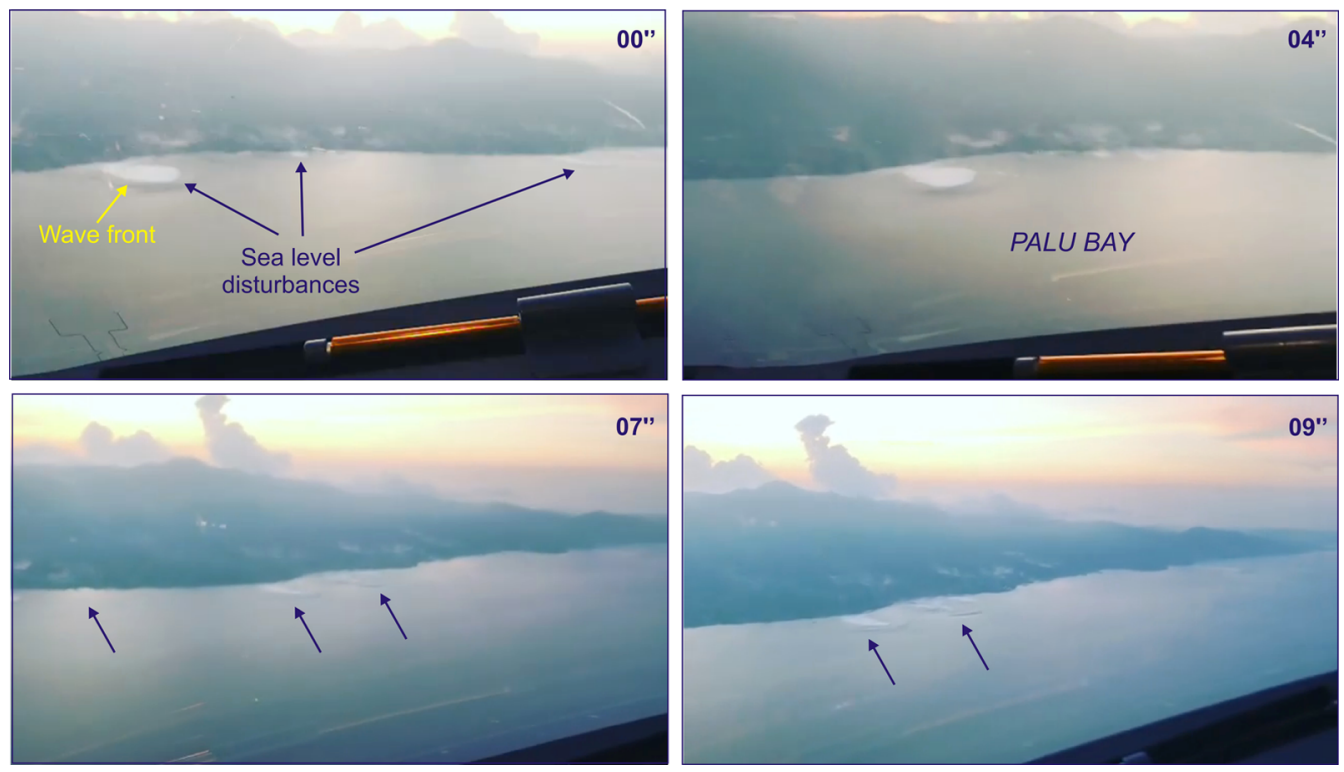

Figure 13

Photo captures indicating sea surface disturbances taken from onboard an aircraft flying over the Palu Bay shortly after the 28 September 2018 Sulawesi earthquake origin time (source of the video: https://www.instagram.com/p/BoRttnsn5po/?taken-by=icoze_ricochet)

significantly depends on the actual nearshore bathymetry/topography, and particularly on the last coastal slope on which runup occurs (Kanoglu and Synolakis 1998).

In early days following the Sulawesi disaster, the potential involvement of a secondary source such as a submarine landslide (e.g., Synolakis et al. 2002) or a splay fault (e.g., Plafker, 1972) was mentioned. Both phenomena have been responsible for extremely large tsunamis following moderate earthquakes in the past. The 15-m large tsunami waves in July 1998 in Papua New Guinea were generated by a landslide tsunami following an $M w 7.0$ earthquake (Tappin et al. 2001; Synolakis et al. 2002; Heidarzadeh and Satake, 2015a). Splay fault have been reported to double tsunami heights compared to cases without a splay component (Heidarzadeh et al. 2009). Both splay faults and landslides are local phenomena with limited source dimensions (e.g. a few kilometers). The dimensions of the 1998 PNG landslide were $\sim 4 \mathrm{~km}$ in both length and width. For the 2018 Sulawsi event, a video recording of the sea surface of the Palu Bay shortly after the earthquake, captured onboard an aircraft, shows several local sea surface disturbances (Fig. 13). Another 4-min eyewitness video from onboard a boat also recorded at least three subaerial landslides within the Palu Bay following the earthquake (Fig. 14). Due to the small size of these sea surface disturbances and landslides in the eyewitness videos (Figs. 13, 14), they may not necessarily be of the sizes capable of producing significant tsunamis. It appears that the area is susceptible to subaerial and submarine landslides; therefore, it could be possible that a large submarine landslide along the submerged slopes was responsible for the 6-11 $\mathrm{m}$ tsunami waves. Potential contribution of such secondary sources (i.e., co-seismic landslides) could be examined by acquisition and interpretations of marine geological data from the seafloor within the Palu Bay.

Ideas of the existence of a tsunami generation mechanism other than the strike-slip fault might be strengthened by findings from field surveys (Muhari et al. 2018) which revealed that maximum inundation of the tsunami was limited to the areas within $400 \mathrm{~m}$ from the shoreline. Due to their short-period waves, landslide-generated waves are not capable of producing long inundations. From the hydrodynamics point of view, inundation distance strongly depends on the period of the waves: the longer the period of the waves, the longer the inundation distance. The short-period waves inside the bay (Pantoloan, Fig. 1b) and rapid arrival time onshore may indicate 

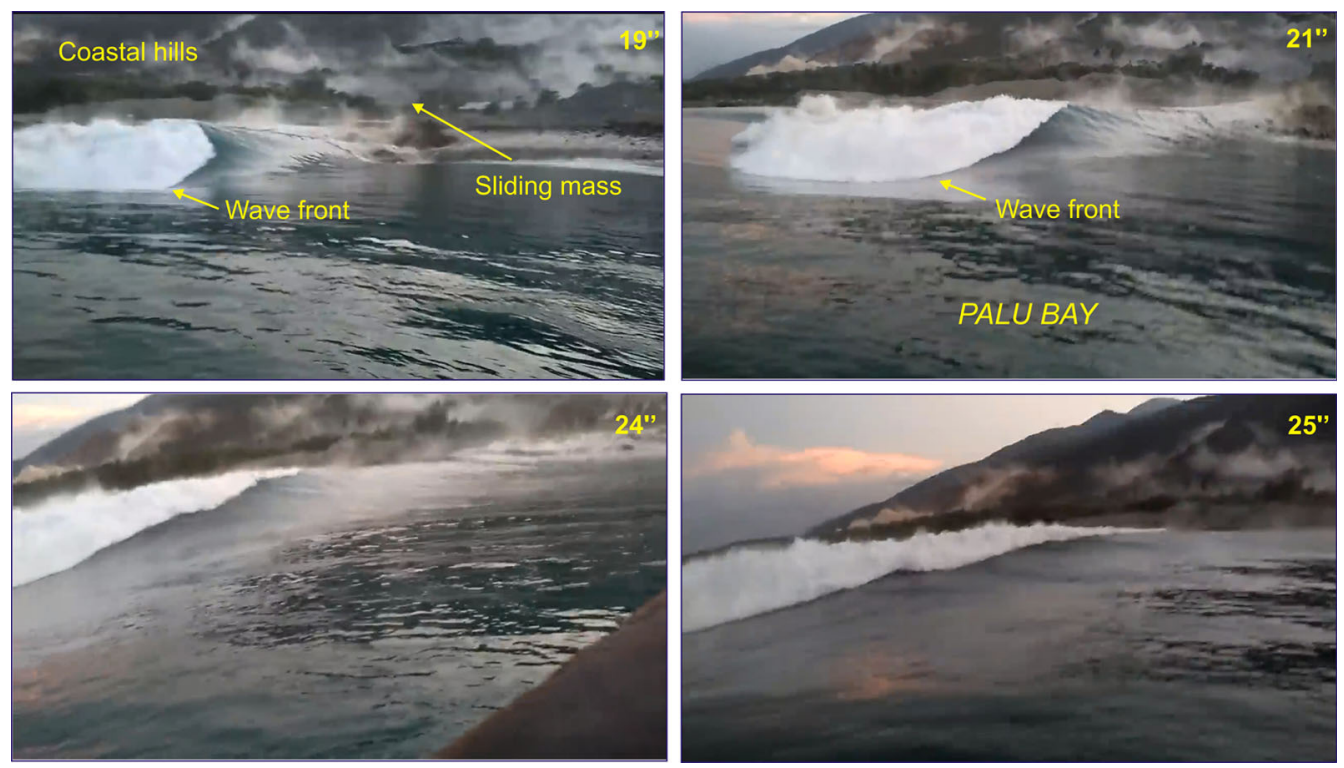

Figure 14

Photo captures showing the generation and propagation of a subaerial landslide taken from onboard a boat within the Palu Bay shortly after the origin time of the 28 September 2018 Sulawesi earthquake (source of the video: https://www.youtube.com/watch?time_continue=2\&v= 61ItBglP-YM)

that tsunami might have been generated inside the bay by a relatively small source. This wave severely impacted on infrastructures and buildings at the front row near by the coastline (Fig. 2), however, the waves were not strong enough to penetrate further inland as the inundation line was found not more than $400 \mathrm{~m}$ landward.

A main challenge for the source studies of the Sulawesi tsunami is the lack of enough sea level observations. Only two tide gauge records are available; i.e., Pantoloan and Mamuju. For inside the Palu Bay, where the extreme tsunami waves of 6-11 m were observed, only one sea level record is available (i.e., Pantoloan). The water waves from local phenomena such as submarine landslides usually travel short distances and decay rapidly (Fritz et al. 2004;
McFall and Fritz, 2016; Heidarzadeh and Satake, 2017a,b); hence, even if we assume that a submarine landslide was involved, it is uncertain whether the single sea level record has captured such short-period and short-lasting waves or not.

A combination of spectral analysis, numerical simulations and field data may lead us to two different sources/mechanisms for the tsunamis recorded in Pantoloan and Mamuju. For the Pantoloan record, the inferred source dimension of 3-4 km (Table 2) could be from a small submarine landslide; approximately with the same size as that of the 1998 PNG landslide tsunami. The larger source dimension of $32.5 \mathrm{~km}$ (Table 2) inferred from the Mamuju record is in agreement with the size of the initial co-seismic crustal displacement shown in Fig. 6c, d.

Table 2

Estimates of tsunami source dimensions using the tsunami dominating periods

\begin{tabular}{lllll}
\hline & Period band (min) & Dominating periods (min) & Water depth (m) & Source length (km) \\
\hline Pantoloan & $2.8-6.7$ & $3.6-4.4$ & 100 & $3.4-4.1$ \\
Mamuju & $4.0-18.3$ & 10.0 & 1200 & 32.5 \\
\hline
\end{tabular}




\section{Conclusions}

The 28 September 2018 Sulawesi tsunami was analyzed using sea level data and numerical modeling of tsunami. Main findings are:

1. The maximum tsunami wave height at two tide gauge stations of Pantoloan (within the Palu Bay) and Mamuju (outside the Bay) were 380 and 24 $\mathrm{cm}$, respectively. The respective dominant wave periods were 3.6-4.4 and $10.0 \mathrm{~min}$. The highenergy waves at Pantoloan lasted for $5.5 \mathrm{~h}$ while they lasted for at least $14 \mathrm{~h}$ in Mamuju. The two observed waveforms were significantly different with wave amplitude and period ratios of $\sim 16$ and $\sim 3$, respectively.

2. Based on the results of spectral analyses of the tsunamis recorded inside (i.e., Pantoloan) and outside (i.e., Mamuju) of the Palu Bay, the dimensions of the tsunami sources are estimated at $3.4-4.1 \mathrm{~km}$ and $32.5 \mathrm{~km}$, for inside and outside of the Palu Bay, respectively.

3. Numerical simulations of the tsunami using a purely-tectonic source model based on USGS were capable of fairly well reproducing both observation tide gauge records in Pantoloan and Mamuju; except for arrival time in Mamuju. Our simulations (excluding runup calculations) resulted in maximum coastal amplitudes of $\sim 1.5 \mathrm{~m}$ which is far less than the observed runup of 6-11 m. After acquiring highresolution bathymetry/topography data and having a full understanding of runup field data, the model needs to be re-run.

4. Evidence may indicate the occurrences of submarine landslides following the Sulawesi event which potentially contributed to and intensified the main tectonic tsunami; such as the actual sea surface disturbances captured by video recordings from onboard an airplane and a boat within the Palu Bay. Submarine landslides could be responsible for extreme local runup heights; however, marine geological data need to be acquired from the Palu Bay to confirm such hypotheses. We identify the southern part of the Palu Bay, around the latitude of $-0.82^{\circ} \mathrm{S}$, as the most likely location of a potential landslide based our backward tsunami ray tracing analysis.

\section{Acknowledgements}

Two tide gauge records in Pantoloan and Mamuju were provided by the Agency for Geo-spatial Information, Indonesia (BIG) (http://tides.big.go.id). We sincerely thank scientists in BIG including Andi Eka Sakya, Hasanuddin Z Abidin and Mohamaad Arief Syafi'i for their efforts to provide the data in a timely manner. The Latu Datu tide gauge data were downloaded from the Intergovernmental Oceanographic Commission website (http://www. iocsealevelmonitoring.org/). The earthquake source model used in this study is based on that of USGS (https://earthquake.usgs.gov/earthquakes/eventpage/ us 1000h3p4/finite-fault). We are grateful to scientists in the USGS Earthquake Hazards Programs for making the source model publically available. We used the GMT software by Wessel and Smith (1998) in this study. We sincerely thank Alexander Rabinovich (Editor-in-Chief) for reading and commenting on the early version of this article and for producing Table 1. Results of spectral analyses were discussed with Alexander Rabinovich. We received help from Satoko Murotani (National Museum of Nature and Science, Tsukuba, Japan) for the analysis of vertical water displacement due to steep slopes. We sincerely thank two anonymous reviewers and Alexander Rabinovich (Editor-in-Chief) for their constructive review comments. $\mathrm{MH}$ is grateful to the Brunel University London for the funding provided through the Brunel Research Initiative and Enterprise Fund 2017/18 (BUL BRIEF).

Open Access This article is distributed under the terms of the Creative Commons Attribution 4.0 International License (http:// creativecommons.org/licenses/by/4.0/), which permits unrestricted use, distribution, and reproduction in any medium, provided you give appropriate credit to the original author(s) and the source, provide a link to the Creative Commons license, and indicate if changes were made.

Publisher's Note Springer Nature remains neutral with regard to jurisdictional claims in published maps and institutional affiliations. 


\section{REFERENCES}

Bellier, O., Sébrier, M., Beaudouin, T., Villeneuve, M., Braucher, R., Bourles, D., et al. (2001). High slip rate for a low seismicity along the Palu-Koro active fault in central Sulawesi (Indonesia). Terra Nova, 13(6), 463-470.

Borrero, J. C., McAdoo, B., Jaffe, B., Dengler, L., Gelfenbaum, G., Higman, B., et al. (2011). Field survey of the March 28, 2005 Nias-Simeulue earthquake and tsunami. Pure and Applied Geophysics, 168(6-7), 1075-1088.

Fujii, Y. \& Satake, K. (2006). Source of the July 2006 West Java tsunami estimated from tide gauge records. Geophysical Research Letters, 33(24), L24317. https://doi.org/10.1029/ 2006GL028049

Fritz, H. M., Hager, W. H., \& Minor, H. E. (2004). Near field characteristics of landslide generated impulse waves. Journal of Waterway Port Coastal and Ocean Enineering., 130, 287-302.

Heidarzadeh, M., Pirooz, M. D., \& Zaker, N. H. (2009). Modeling the near-field effects of the worst-case tsunami in the Makran subduction zone. Ocean Engineering, 36(5), 368-376.

Heidarzadeh, M., \& Satake, K. (2013). The 21 May 2003 tsunami in the Western Mediterranean Sea: Statistical and wavelet analyses. Pure and Applied Geophysics, 170(9), 1449-1462.

Heidarzadeh, M., \& Satake, K. (2014). Excitation of Basin-Wide Modes of the Pacific Ocean Following the March 2011 Tohoku Tsunami. Pure and Applied Geophysics, 171(12), 3405-3419.

Heidarzadeh, M., \& Satake, K. (2015a). Source properties of the 1998 July 17 Papua New Guinea tsunami based on tide gauge records. Geophysical Journal International, 202(1), 361-369.

Heidarzadeh, M., \& Satake, K. (2015b). New Insights into the Source of the Makran Tsunami of 27 November 1945 from Tsunami Waveforms and Coastal Deformation Data. Pure and Applied Geophysics, 172(3), 621-640.

Heidarzadeh, M., Harada, T., Satake, K., Ishibe, T., \& Takagawa, T. (2017). Tsunamis from strike-slip earthquakes in the Wharton Basin, northeast Indian Ocean: March 2016 M w7. 8 event and its relationship with the April 2012 M w 8.6 event. Geophysical Journal International, 211(3), 1601-1612.

Heidarzadeh, M., \& Satake, K. (2017). Possible dual earthquakelandslide source of the 13 November 2016 Kaikoura, New Zealand tsunami. Pure and Applied Geophysics, 174(10), 3737-3749.

Heidarzadeh, M., Satake, K. (2017b). A Combined EarthquakeLandslide Source Model for the Tsunami from the 27 November 1945 M 8.1 Makran Earthquake. Bulletin of the Seismological Society of America, 107 (2), 1033-1040.

Imamura, F., Shuto, N., Goto, C. (1988). Numerical simulation of the transoceanic propagation of tsunamis. In: Proceedings of 6 th Congress Asian and Pacific Regional Division, IAHR, Japan.

Imamura, F., Muhari, A., \& Arikawa, T. (2018). Field survey of Palu Tsunami, 20180928, http://irides.tohoku.ac.jp/media/files/ earthquake/eq/2018_sulawesi_eq/Preriminary_Field_Survey_ Report_20181008b2.pdf

Kânoğlu, U., \& Synolakis, C. E. (1998). Long wave runup on piecewise linear topographies. Journal of Fluid Mechanics, 374, $1-28$.

Hamzah, L., Puspito, N. T., \& Imamura, F. (2000). Tsunami catalog and zones in Indonesia. Journal of Natural Disaster Science, 22(1), 25-43.
Liu, P. L.-F., Woo, S.-B., \& Cho, Y.-S. (1998). Computer programs for tsunami propagation and inundation. Technical Report, Cornell University, Ithaca, N.Y.

McFall, B. C., \& Fritz, H. M. (2016). Physical modelling of tsunamis generated by three-dimensional deformable granular landslides on planar and conical island slopes. Proceedings of Royal Society London A, 472(2188), 20160052.

Muhari, A., Imamura, F., Arikawa, T., Hakim, A., \& Afriyanto, B. (2018). Solving the Puzzle of the September 2018 Palu, Indonesia, Tsunami Mystery: Clues from the Tsunami Waveform and the Initial Field Survey Data. Journal of Disaster Research, 13, sc20181108.

Okada, Y. (1985). Surface deformation due to shear and tensile faults in a half-space. Bulletin of the Seismological Society of America, 75, 1135-1154.

Okal, E. A., Synolakis, C. E., Uslu, B., Kalligeris, N., \& Voukouvalas, E. (2009). The 1956 earthquake and tsunami in Amorgos. Greece. Geophysical Journal International, 178(3), 1533-1554.

Okal, E. A., \& Synolakis, C. E. (2004). Source discriminants for near-field tsunamis. Geophysical Journal International, 158(3), 899-912.

Plafker, G. (1972). Alaskan earthquake of 1964 and Chilean earthquake of 1960: Implications for arc tectonics. Journal of Geophysical Research, 77(5), 901-925.

Pelinovsky, E., Yuliadi, D., Prasetya, G., \& Hidayat, R. (1997). The 1996 Sulawesi tsunami. Natural Hazards, 16(1), 29-38.

Rabinovich, A. B., Lobkovsky, L. I., Fine, I. V., Thomson, R. E., Ivelskaya, T. N., \& Kulikov, E. A. (2008). Near-source observations and modeling of the Kuril Islands tsunamis of 15 November 2006 and 13 January 2007. Advances in Geosciences, 14, 105-116.

Rabinovich, A.B. (2010). Seiches and harbor oscillations. in: Handbook of coastal and ocean engineering (pp. 193-236).

Satake, K., Nishimura, Y., Putra, P. S., Gusman, A. R., Sunendar, H., Fujii, Y., et al. (2013a). Tsunami source of the 2010 Mentawai, Indonesia earthquake inferred from tsunami field survey and waveform modeling. Pure and Applied Geophysics, 170(9-10), 1567-1582.

Satake, K., Fujii, Y., Harada, T., \& Namegaya, Y. (2013b). Time and space distribution of coseismic slip of the 2011 Tohoku earthquake as inferred from tsunami waveform data. Bulletin of the Seismological Society of America, 103(2B), 1473-1492.

Satake, K. (2014). Advances in earthquake and tsunami sciences and disaster risk reduction since the 2004 Indian Ocean tsunami. Geoscience Letters, 1(1), 15.

Synolakis, C.E. (2003). Tsunami and seiche. In: Chen, W.F., Scawthorn, C. (Eds.), Earthquake Engineering Handbook. CRC Press. Chapter 9, 1-90.

Synolakis, C.E., \& Okal, E.A. (2005). 1992-2002: Perspective on a decade of post-tsunami surveys. in: Tsunami, ed. by K. Satake, Advances in Natural and Technological Hazards, 23, 1-30, 2005.

Synolakis, C. E., \& Kong, L. (2006). Runup measurements of the December 2004 Indian Ocean tsunami. Earthquake Spectra, 22(S3), 67-91.

Synolakis, C.E., Bardet, J.P., Borrero, J.C., Davies, H.L., Okal, E.A., Silver, E.A., Sweet, S. \& Tappin, D.R. (2002). April. The slump origin of the. (1998). Papua New Guinea tsunami. Proceedings of the Royal Society of London A, 458(2020), 763-789. 
Tanioka, Y., \& Satake, K. (1996). Tsunami generation by horizontal displacement of ocean bottom. Geophysical Research Letters, 23(8), 861-864.

Tappin, D. R., Watts, P., McMurtry, G. M., Lafoy, Y., \& Matsumoto, T. (2001). The Sissano, Papua New Guinea tsunami of July 1998-offshore evidence on the source mechanism. Marine Geology, 175(1-4), 1-23.

Wang, X., \& Liu, P. L.-F. (2006). An analysis of 2004 Sumatra earthquake fault plane mechanisms and Indian Ocean tsunami. Journal of Hydraulic Research, 44, 147-154.
Weatherall, P., Marks, K. M., Jakobsson, M., Schmitt, T., Tani, S., Arndt, J. E., et al. (2015). A new digital bathymetric model of the world's oceans. Earth Space Science, 2, 331-345.

Welch, P. (1967). The use of fast Fourier transform for the estimation of power spectra: A method based on time averaging over short, modified periodograms, IEEE Transactions Audio Electroacoustics, AE-15, 70-73.

Wessel, P., \& Smith, W. H. F. (1998). New, improved version of generic mapping tools released. EOS Trans AGU, 79(47), 579.

(Received October 26, 2018, revised November 23, 2018, accepted November 26, 2018, Published online December 17, 2018) 